\title{
DEVELOPMENT OF QUANTUM LEARNING LEARNING MODEL THROUGH ARISAN CARDS TO INCREASE STUDENT MOTIVATION AND LEARNING OUTCOMES
}

\author{
Fitri Rahmawati ${ }^{\left.a^{*}\right)}$, Muhamad Sutisna ${ }^{b)}$ \\ ${ }^{a)}$ SMPN 13 Kota Serang, Serang, Indonesia \\ ${ }^{b)}$ STKIP Arrahmaniyah, Depok, Indonesia \\ ${ }^{*}$ Corresponding Author: firaw26@gmail.com
}

Article history: received 09 January 2021; revised 13 February 2021; accepted 26 February 2021

\begin{abstract}
The low learning motivation and learning outcomes of students occur because there are several problems such as the attitude of students who are indifferent to the learning process, students do not pay attention when the teacher explains the material and do not do the assignments given by the teacher, the lack of interest of students in Pancasila Education subjects and Citizenship. This study aims to find a quantum learning model through arisan cards to increase student motivation and learning outcomes. The research method used Research and Development This research was conducted in three product trials. The subjects of this study were class VIII students with 36 students in the 2019-2020 school year. Data collection techniques include expert verification sheet learning models, verification of material experts, observation of learning motivation and student learning outcomes, interview sheets and documentation. The results showed; The percentage of observation results of learning motivation and learning outcomes of students in the first trial, namely motivation by $58 \%$, pretest by $50 \%$, and postest by $56 \%$. In the second trial, the motivation was $61 \%$, the pretest was $61 \%$, and the postest was $68 \%$. And in the third trial, namely motivation by $80 \%$, pretest by $77 \%$, and postest by $85 \%$. This study concludes that the design of the Quantum Learning learning model through the Arisan Card can improve learning motivation and student learning outcomes in the material order of the order of laws in the national legal system in Indonesia.
\end{abstract}

Keywords: quantum learning, arisan cards, learning motivation, learning outcomes

\section{INTRODUCTION}

The Quantum Learning learning model is a learning model that can help teachers and students increase motivation and learning outcomes in school, in its application this learning model is presented in a fun, relaxed, and interesting way so that lessons are easily accepted by students, with good application. attracting students who are motivated to take part in learning that makes students active in learning in the classroom. All students in the group are required to be active so that they are not dominated by one or two students. This is suitable for class VIII students of SMP Negeri 13 Serang City who have the potential to develop more.

The benefits of learning through Quantum Learning include students being able to; (1) have a positive attitude, (2) generate motivation, (3) have learning skills, (4) have self-confidence, (5) can improve learning outcomes [1]. The Quantum Learning Model is based on the assumption that all life is energy that can be converted into light. Quantum Learning Learning Model in the form of arisan cards is one of the models in teaching that has advantages or advantages in terms of interesting learning connected to real life. The arisan card is said to be a learning model, because the arisan card is a group learning, where students work together in groups to discuss the suitability of the answers to each question that comes out of the glass that has been shaken by the teacher [2].
If the learning of the social gathering card model is applied, it can motivate students to learn because it is interesting and fun for students. Learning through the arisan card model, students feel that doing play activities will be easy to understand a concept that is being studied. On the basis of this it can improve learning outcomes [3]. The learning model through arisan cards is a group learning model, where students can collaborate to discuss adjusting the answers to the questions that come out of the glass that has been shaken by the teacher [4]. Hamzah B. Uno emphasized that learning through the arisan card model is a strategy to stimulate student participation to provide answers to the questions listed on the arisan card that the teacher shuffles [5].

According to Taufina Taufik, the steps in the Arisan Card Learning Model are several steps, namely [6]: (1) Form groups of 4-5 people heterogeneously. (2) Each student is given one answer card sheet, and the question card is rolled up which is then put in a glass. (3) The questions that are already in the glass are shaken, then one is issued, then read so that the student who has the answer card in accordance with the question can answer. (4) If the student answers correctly gets one point for the group score, (5) the group's score comes from the number of points the group has earned.

The advantages of the Arisan Card Learning Model according to Hamzah B. Uno (2013), namely: (1) Providing opportunities for students to learn actively and apply their learning to real life, (2) This model encourages students to 
interact multidirectional (student-teacher) (3) Creating a varied learning atmosphere (4) This model is studentcentered (5) Student learning outcomes can be improved. While the shortcomings in this social gathering card learning model, namely: (1) It makes it difficult for teachers to teach because there are many media that must be prepared (2) In the learning process it takes a relatively long time (3) If the teacher cannot master the class, the classroom atmosphere will tend not to be used. Directed [7].

The results of research conducted by Irlaila Kusumawardani stated that the application of the quantum learning model through the TANDUR process (Grow, Experience, Name, Demonstrate, Repeat, and Celebrate) can improve the quality of the learning process in Civics subjects. Increasing the learning process, resulting in increased learning motivation of students from pre-action to cycle II. The results of the learning motivation questionnaire, namely the number of students who were in the high, very high, or successful category in the pre-action were 9 students with a percentage of $41 \%$ increasing to 15 students with a percentage of $68 \%$ in cycle I. The number of students who were in the high category, very high or success in cycle II increased again to 19 students with a percentage of $86 \%$.

The design of the Quantum Learning learning model through Arisan Cards, can improve learning motivation and student learning outcomes on the material order of the order of laws in the national legal system in Indonesia. Because the Quantum Learning model of learning through Arisan Cards is interesting and fun for students. The Quantum Learning learning model through Arisan Cards is also a group learning model to discuss the suitability of the answers to each question. They also do not become bored and want to be excited about learning because they are playing while learning. If the quantum learning model design through the Arisan Card is used, it can motivate students to learn. In addition, through playing activities they will also easily understand the concepts being learned, thus learning outcomes will increase.

\section{RESEARCH METHODS}

In this study, researchers chose the research location at SMPN 13 Serang City. The time of this research was started from August 2019 to January 2020. The research method used was the Research and Development (R\&D) method. The reason for using the Research and Development development model is because this model covers all things related to development to produce innovative learning models. quantum learning through Arisan Cards in this study. In this study, the Research and Development steps were adjusted by simplifying them into 6 steps, namely: (1) Potentials and Problems, (2) Data collection, (3) Product Design, (4) Design Validation, (5) Revision Design, (6) Production of Learning Models. So that later the product will be produced in the form of a learning model. [8] Respondents in this study were students of class VIII SMP Negeri 13 Serang City. The instruments used include the expert verification sheet for learning models, verification of material experts, observation of learning motivation and student learning outcomes, interview sheets and documentation. The instrument used meets the standard because it is prepared using standard instrument development procedures and its accuracy can be accounted for [9].

\section{RESULTS AND DISCUSSION}

\section{a. Product Design}

The success of learning using a quantum learning model is very dependent on the development of a variety of model designs that will be presented. The design of the model that will be presented is an interactive, attractive model, which is adapted to the material to be given, right on target learning objectives so that it can increase students learning motivation while in the school environment of SMP Negeri 13 Serang City. The arisan card developed is a card with a size $10 \times 10 \mathrm{~cm}$ is made as many as the number of students for answers and cards with a size of $5 \times 5 \mathrm{~cm}$ are made as many as the number of students for questions/questions, and the paper used to make arisan cards is white hvs.

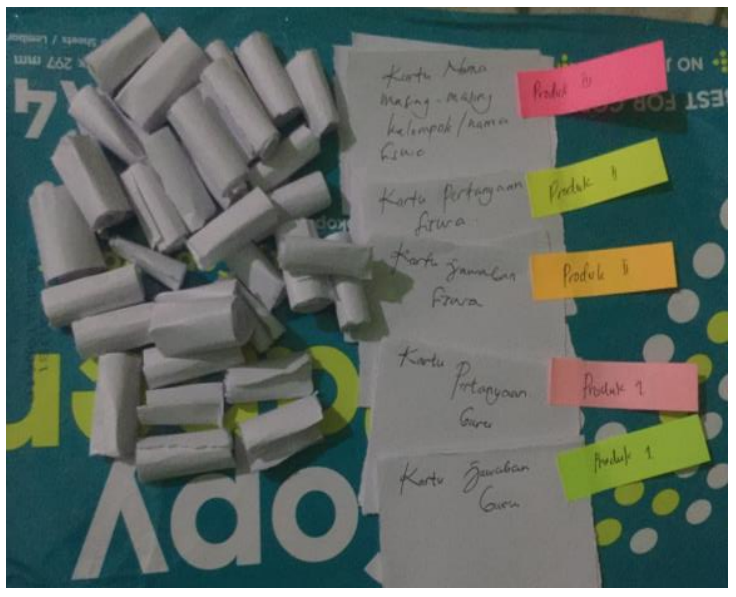

Figure 1. Initial Product Design

\section{b. Design Validation}

Validation is the extent to which the accuracy and speed of a measuring instrument performs its measuring function and reliability is the extent to which the results of a measurement can be trusted. Design validation is used to assess quantum learning models that are developed both in terms of material, development, applicability, and the impact of the quantum learning model. To find out, individual and group validation was carried out based on the prepared guidelines. Individual validation is carried out by material experts and learning model experts. The material experts chosen were lecturers of the PPKn S2 study program, namely three experts in learning models and material experts.

The product of the quantum learning model through arisan cards is validated by experts. There are three experts 
who validate the quantum learning model model through arisan cards, namely learning evaluation experts, PPKn material experts and learning model experts. The validity level of the quantum learning model through the social gathering card learning model is known through the results of the analysis of trial activities carried out in two stages, namely: (1) Testing of learning evaluation experts, subject matter experts and learning model experts. This serves as a review of the initial product as a basis for revision. (2) Questionnaire students' responses. This activity was carried out to find out how much students enjoyed learning with the quantum learning model through the arisan card learning model in PPKn subjects. Group validation was carried out by teachers who taught at SMP Negeri 13 Serang City using the quantum learning model through arisan cards. renewable ones.

\section{c. Design Revision}

Design revision is used to revise weaknesses and improve learning models based on design validation. After the validation stage is carried out, then a design revision is carried out. Model learning experts provide some general comments and suggestions for improvement. The quantum learning model through arisan cards was then revised according to comments and suggestions from the two validators, namely answer cards and question/question cards made by the teacher using colorful hvs paper to make students more interested, as well as a container for putting answer cards and cards. questions/questions are made by the teacher so that question/question cards are rolled up and then put into the container while the answer cards are distributed to students.

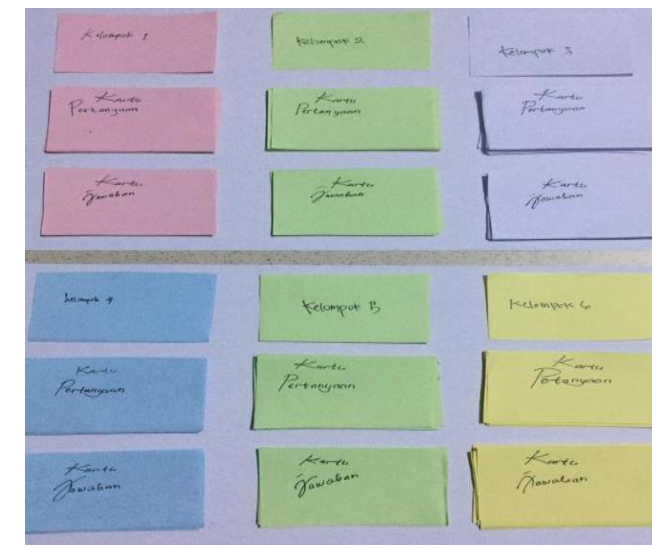

Figure 2. Initial Product Design Revision

\section{d. First Product Trial}

Planning; In planning activities the teacher must prepare several things as follows: (1) The teacher prepares the source of learning materials and media that will be used, compiles and prepares learning tools in the form of a syllabus and lesson plan (RPP), (2) Making a summary of the material, (3) Arranging assessment tools in the form of quantum learning observation sheets through the social gathering card learning model, learning motivation and learning outcomes of students, (4) Developing interview guidelines, (5) Developing learning evaluation tools according to the indicators of learning motivation and learning outcomes

Implementation; At this stage, actions are carried out in the form of implementing a learning program, data collection and observation sheets.

Observation; Observation includes the procedure for recording data about the process and results of the implementation of the development carried out.

\section{e. First Product Revision Into Second Product}

In the form of a description of the analysis procedure for the results of monitoring and revision relating to the process and impact of the development of improvements carried out, as well as the criteria and plans for subsequent developments, namely the arisan card developed in the form of a card with a size of $10 \times 10 \mathrm{~cm}$ to write answers as many as the number of students and a card with a size of $5 \times 5 \mathrm{~cm}$ for questions/questions to write as many as the number of students for questions/questions. Answer cards and question/question cards are no longer made by the teacher but made by students.

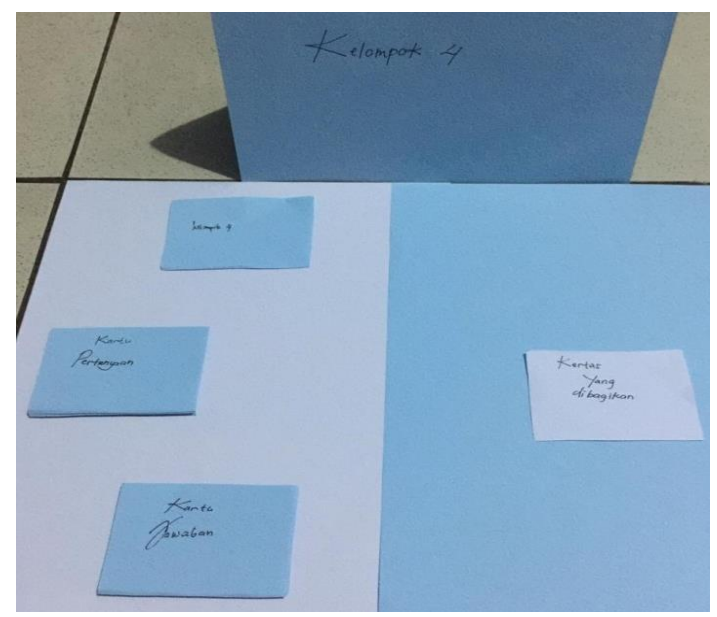

Figure 3. Revision of the First Product to Become the Second Product

\section{f. Second Product Trial}

a. Planning; The researcher made a learning plan based on the revised results in the first product trial.

b. Implementation; The teacher carries out the learning based on the revised learning plan results in the first product trial.

c. Observation; Researchers made observations of learning activities.

\section{g. Second Product Revision Into Third Product}

The researcher revised the implementation of the second product development and prepared a plan (replaning) for the third product trial, namely the social gathering card developed in the form of a card with a size of $10 \times 10 \mathrm{~cm}$ to write answers as many as the number of students and a card 
with a size of $5 \times 5 \mathrm{~cm}$ for questions/questions to write as many the number of students for the questions/questions, a card with a size of $5 \times 5 \mathrm{~cm}$ to write the name of each student, as well as a place to put the card. Answer cards and question/question cards were made by students and students made business cards, which were put into the container no longer a question/question card but the name card of each student.

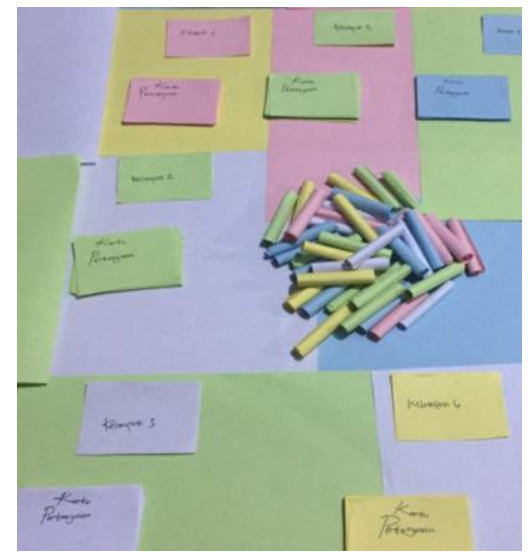

Figure 4. Revision of Second Product to Become Third Product

\section{h. Third Product Trial}

a. Planning; The researcher made a learning plan based on the revised results in the second product trial.

b. Implementation; The teacher carries out the learning based on the revised learning plan in the second product trial.

c. Observation; Researchers made observations of learning activities.

\section{i. The Second Product Revision Becomes a Learning Model}

Researchers made revisions to the implementation of the third product trial and analyzed and made conclusions on the implementation of learning that had been planned by carrying out certain specific developments. Whether learning that has been packaged with certain developments can improve or improve the problems studied in the Research and Development.
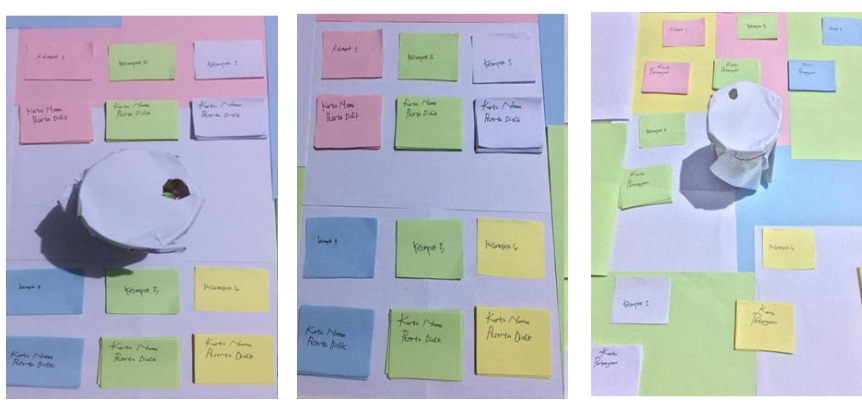

Figure 5. Revision of the Third Product to Become a Learning Model
Table 1. Recapitulation of Research Instruments on Learning Motivation and Student Learning Outcomes

\begin{tabular}{|c|c|c|c|c|}
\hline $\begin{array}{c}\text { Research } \\
\text { Instrument }\end{array}$ & $\begin{array}{c}\text { Product } \\
\text { Trial }\end{array}$ & \multicolumn{2}{|c|}{ Average } & Criteria \\
\hline \multirow{2}{*}{$\begin{array}{c}\text { Learning } \\
\text { Motivation }\end{array}$} & I & \multicolumn{2}{|c|}{58} & Moderate \\
\cline { 2 - 5 } & II & \multicolumn{2}{|c|}{61} & Moderate \\
\cline { 2 - 5 } & III & \multicolumn{2}{|c|}{80} & High \\
\hline \multirow{3}{*}{$\begin{array}{c}\text { Learning } \\
\text { Outcomes }\end{array}$} & & Pretest & Postest & \\
\cline { 2 - 5 } & I & 50 & 56 & Moderate \\
\cline { 2 - 5 } & II & 61 & 68 & Moderate \\
\cline { 2 - 5 } & & 75 & 85 & High \\
\hline
\end{tabular}

From the table 1, it can be explained in Learning Motivation, the results of Product I Trials, namely with an average of 58 are included in the moderate criteria, the results of Product II with an average of 61 are in the Medium criteria and the results of Product Trial III are average Average of 80 falls into the High criteria. Whereas in the Learning Outcomes, the results of the Product I Trial, namely the Pretest with an average of 50 and 56 of the posttest were included in the Medium criteria, the results of the Product II Trial namely Pretest with an average of 61 and postest68 were included in the Medium criteria and the results of the Product Trial III were Pretest with an average of 75 and postest of 85 fit into the High criteria.

\section{Results of Recapitulation of Learning Motivation and} Learning Outcomes of Students

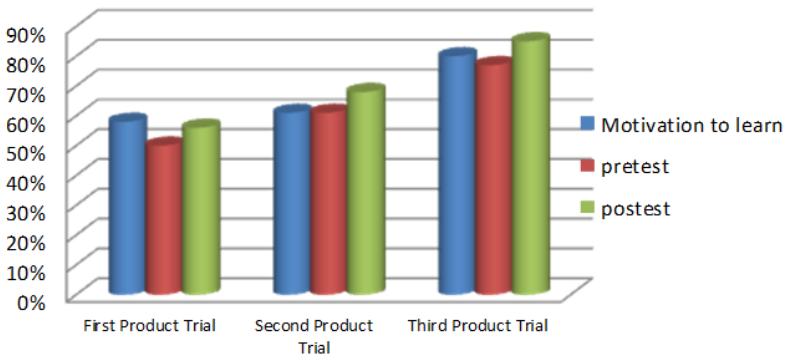

Figure 6. Results of Recapitulation of Learning Motivation and Student Learning Outcomes

Based on the diagram above, it can be seen the percentage of observations of learning motivation and learning outcomes of students in the first trial, namely motivation by $58 \%$, pretest by $50 \%$, and postest by $56 \%$. In the second trial, the motivation was $61 \%$, the pretest was $61 \%$, and the postest was $68 \%$. And in the third trial, namely motivation by $80 \%$, pretest by $77 \%$, and postest by $85 \%$.

\section{CONCLUSION}

Based on the data that has been obtained, conclusions can be drawn based on the formulation of the problems that have been made previously, which are as follows: the design of the Quantum Learning learning model through the Arisan Card can increase learning motivation and student learning outcomes in the material order order of laws and regulations in the legal system in Indonesia, the feasibility of the 
Quantum Learning learning model through the Arisan Card can increase learning motivation and student learning outcomes on the material order of the order of laws in the national legal system in Indonesia and the effectiveness of the Quantum Learning learning model through the Arisan Card can increase learning motivation and results. learn from students on the material order of the order of laws and regulations in the national legal system in Indonesia.

1. In the teaching and learning process by developing the design of the Quantum Learning learning model through the Arisan Card, it can increase learning motivation and student learning outcomes on the material for ordering the order of laws in the national legal system in Indonesia, in the initial trials there are still several obstacles, including students still need adaptation to the learning model that is being developed so that there is still a lack of level of learning motivation and student learning outcomes.

2. The feasibility of the Quantum Learning learning model through Arisan Cards can increase learning motivation and student learning outcomes in the material order of the order of laws in the national legal system in Indonesia.

3. As well as the effectiveness of the Quantum Learning learning model through the Arisan Card, it can increase learning motivation and student learning outcomes in the material order of the order of laws in the national legal system in Indonesia. But in the effectiveness, there may be obstacles and there must be a solution so that every development of the Quantum Learning learning model through the Arisan Card can increase learning motivation and student learning outcomes can run well, therefore researchers develop as a solution to overcome existing obstacles. The following is the development carried out to overcome these obstacles, namely: (1) Provide a reexplanation of the steps of the social gathering card learning model to students so that they can understand and adapt to the learning model that is being carried out (2) Repeating the material so that students understand with the material being taught (3) Providing understanding to students so that they can appreciate when a friend is talking or is expressing his opinion (4) Providing assertiveness to each student so as not to make a fuss and if there is still a fuss then the consequences will be ( 5) Provide understanding to students so that they are not shy and afraid to express their opinions.

After the development of the quantum learning model through arisan cards, learning motivation and student learning outcomes began to experience a significant increase based on the data that had been obtained.

\section{REFERENCES}

[1] Bobbi DePorter dan Mike Hernacki, 68 Model Pembelajaran Inovatif dalam Kurikulum. Yogyakarta: Ar-Ruzz Media, 2013.
[2] Gusnita, Jurnal penelitian :Pengaruh Model Pembelajaran Kooperatif Kartu ArisanTerhadap Hasil Belajar PknSsiswa Kelas VIISMP Negeri 1 Kampar Timur Kabupaten Kampar, Riau: Universitas Riau Press. 2015.

[3] Nurhayani, Metode Kartu Arisan, Tersedia pada http://nurhay13.blogspot.co/2011/metode_kartu_arisa n.html(diakses pada tanggal 02 Juli 2020)

[4] Ari Susanti, Penerapan Model Pembelajaran Kartu Arisan Untuk Meningkatkan HasilBelajar IPA Siswa Kelas V Semester Ganjil SD No 2 Mendoyo, Jurnal Jurusan PGSD UniversitasPendidikan Ganesha Singaraja, hlm. 4.

[5] Hamzah B. Uno dan Nurdin Mohamad, Belajar dengan Pendekatan PAILKEM, Jakarta: PT. Bumi Aksara, 2013.

[6] Taufina Taufik, Mozaik Pembelajaran Inovatif Padang: Sukabina Press, 2010.

[7] Hamzah B. Uno dan Nurdin Mohamad, Belajar dengan Pendekatan PAILKEM, Jakarta: PT. Bumi Aksara. 2013.

[8] Sri Rahayu, Penelitian Pendidikan, Yogyakarta: Media Akademi. 2019.

[9] Pudjiastuti, Sri Rahayu, Sri Rumiati. 2019 Development of the PKn Learning Attitude Assesment Model in Foreign Political Culture and Results of PKn Learning from Students of Depok City Vocational School (SMK Semesta Cimanggis). JhSS Journal of Humanities and Social Studies, eISSN:2598-120X | p-ISSN:2598-117X. Sinta-3. Vol. 3, No.1. 